\title{
Beyond greed and grievance in Sierra Leone
}

\section{Can diamonds play a role in post-conflict reconstruction?}

\begin{abstract}
African countries with significant natural wealth have often reaped limited rewards and have experienced underdevelopment, corruption, political instability, and in some cases, violent conflict. As a result, the so-called 'resource curse' hypothesis has received much attention in recent years. It has been suggested that diamonds played a key role in fuelling the brutal civil war in Sierra Leone during the 1990s, an issue that has given rise to a significant literature on 'blood diamonds'. However, as Sierra Leone emerges from a decade of destruction, field-based research undertaken in the Eastern Province suggests that diamonds could actually provide an important impetus for post-war reconstruction. Following a review of the 'resource curse' literature and its relevance to Sierra Leone, two important initiatives in the country's diamond economy are then examined: the Kimberley Process Certification Scheme (KPCS) and the Diamond Area Community Development Fund (DACDF). The paper argues that whilst such initiatives are undoubtedly significant steps in addressing a number of key issues, such strategies need to be managed carefully and future policies must be based on a detailed understanding of relationships between diamond mining and broader development strategies and priorities. Keywords: Sierra Leone, diamonds, economies of violence, post-conflict reconstruction
\end{abstract}

\section{Introduction}

In recent years, analysts of war have often explained conflict in Africa either as a consequence of Malthusian factors associated with resource scarcity, or ethnic divisions and competition linked to longstanding tribal hatred. In 1994, Robert Kaplan's foray into the "coming anarchy" in West Africa painted an apocalyptic vision of how scarcity, crime, overpopulation, tribalism and disease were destroying the social fabric of society and plunging many African states into violent barbarism (KAPLAN 1994). Although Kaplan's neo-Malthusian understanding of the relationship between population growth, eco-scarcity and violence has been heavily criticised on the grounds that it distorts and misrepresents the issues, his ideas continue to influence foreign policy making towards the South, and sub-Saharan Africa in particular.

Since the emergence of Kaplan's 'new barbarism' thesis, a burgeoning literature on environmental security has developed, largely in an attempt to explain the relationships between war and resources in Africa in a post-Cold War context (e.g. see HoMER-Dixon 1999; MATtHew et al. 2002; BANNON/COLlIER 2003).
As recent academic interest in Africa's civil wars has grown, many observers have drawn a distinction between old conventional wars and the new wars that have ensued since the demise of the Cold War, the latter of which are largely understood as depoliticised criminal processes that are motivated by economic factors (KALDOR 2006; Le BILlON 2001; BeRDAL/ Malone 2000; KeEn 1998). Most notably, DUFFIELD (2001) has suggested that these new wars in Africa have fed into an emerging "development-security complex", where underdevelopment is seen as a key factor leading to instability and global insecurity. DUFFY (2007) adds that notions of environmental security have intersected with this view of underdevelopment, and have conditioned approaches to expanding forms of intervention in Africa, including international responses to humanitarianism and peace keeping.

The Republic of Sierra Leone, the focus of this paper, has frequently been at the centre of attention in discussions concerning environmental security and Africa's new wars. Situated on the West African coast, between Guinea and Liberia, Sierra Leone is one of four former British colonies in West Africa (The Gambia, 
Sierra Leone, Ghana (formerly Gold Coast), and Nigeria), and gained its independence in 1961. With an area of $71,740 \mathrm{~km}^{2}$, Sierra Leone is slightly smaller than Scotland and the US state of South Carolina. Its population was estimated at 6.1 million in July 2007, with an annual population growth rate of $2.3 \%$. It is predominantly an agricultural country, with over two-thirds of the population engaged in family farming, growing rice, the main staple, as well as a range of vegetables, fruits and cash crops such as coffee, cocoa and palm oil. The country is well endowed with mineral resources, notably diamonds, which have been mined since the 1930s, a high proportion of which are gem quality. There are also valuable reserves of bauxite, and the country has one of the world's largest deposits of rutile, a titanium ore which is used as a paint pigment, as well as a whitener in everyday items such as toothpaste and pharmaceuticals. Despite this natural wealth, Sierra Leone has the dubious distinction of being ranked by the United Nations as the second poorest country in the world, after Niger (UNDP 2006). Its per capita Gross Domestic Product (GDP) in 2004 was only US\$ 561, compared with US\$28,303 for Germany, US\$ 30,821 for UK and US\$ 39,676 for the USA. Sierra Leone's under-five mortality rate of 283 per 1,000 live births is the worst in the world, and life expectancy at birth in 2004 was only 41 years. Many factors are responsible for the high levels of poverty in Sierra Leone, but a long period of poor governance, widespread corruption and the civil war in the 1990s are undoubtedly highly significant. What the country now desperately needs is peace and stability engendered by transparent and fair governance at all levels.

It has been suggested that diamonds played a key role in fuelling Sierra Leone's brutal civil war during the 1990s, an issue that has given rise to a considerable literature on so-called 'blood diamonds'. The causes of Sierra Leone's debilitating conflict were multifaceted and complex. Much attention has been focused on the political economy of conflict, both in Sierra Leone (e.g. KEEN 2005; RICHARDS 2003; SMILLIE et al. 2000), and also more widely in other diamond-fuelled wars in Africa, such as those in Angola and the Democratic Republic of Congo (e.g. LE BILlon 2001; United Nations Panel of Experts 2002). In the case of Sierra Leone, considerable debate surrounds the so-called greed vs. grievance thesis ${ }^{1}$ (CoL-
LIER 2000; Berdal/Malone 2000). While some observers suggest that the raison d'etre for the war may not have been to actually win it, but rather "to engage in profitable crime under the cover of warfare" (SMILlie 2000, 24), others argue that there is little evidence to suggest that diamonds were the fundamental cause of the conflict (RICHARDS 2003). However, there is some consensus that diamonds played a key role in fuelling and prolonging the war, as various parties undoubtedly funded their war efforts through mining activities ${ }^{2}$.

With the restoration of peace, the disarmament and demobilization of 71,000 ex-combatants and the successful conclusion of presidential and parliamentary elections in 2002, Sierra Leoneans are now faced with the massive task of reconstructing communities, institutions and structures and re-building livelihoods. The recent passing of the Local Government Act, 2004 is a move that has allegedly seen the state strengthen its position at the local level, and has, in theory, created new spaces for increased interaction between state agencies and communities. By bringing government closer to the people, some optimistic commentators have argued that the decentralization process could be instrumental in alleviating the social exclusion that has been responsible for the marginalization of rural voices in the past. For example, the World Bank, the United Nations Development Programme (UNDP) and the UK's Department for International Development (DfID), all strongly advocate that decentralization should be a prime element of Sierra Leone's post-conflict reconstruction strategy. Lessons concerning good governance can certainly be learned from the past, and some observers argue that a devolution of power could play a key role in strengthening the country's poor track record concerning accountability and transparency in the diamond economy. When President Siaka Stevens and the All People's Congress (APC) party came to power in 1968 , it marked the beginning of a long decline for the diamond industry, and the country at large. As Stevens appointed many of his 'cronies' to positions of power, the wealth from diamonds was used to reward his supporters, and the diamond industry was reduced to a parastatal that was rife with corruption and smuggling. In the following seventeen years that Stevens retained power, the industry went from officially exporting 1.7 million carats at its height in the 1960 s, to a mere 50,000 carats 
by 1985 (TEMPLE 2006). Many commentators have noted that it was this highly centralised regime under Stevens, fuelled by corruption and rent-seeking behaviour associated with diamonds, that was largely responsible for creating a socially excluded underclass in Sierra Leone, which undoubtedly cultivated the preconditions for war.

Tying into debates concerning the development-security complex, the international aspects of Sierra Leone's diamond-conflict nexus are particularly interesting, and there has been increasing recognition that the implications of the country's illicit diamond activities may not be as localized as they were once believed to be. RENO (1995), for example, has argued that the country's illicit shadow state economy, and the local networks that sustain it, are inextricably linked to global networks. Sierra Leonean diamonds have been implicated in regional instability in Liberia, Guinea and Cote D'Ivoire, and also linked to international criminal networks (DAVIES 2006). Since September $11^{\text {th }} 2001$, it has become evident that the illicit diamond trade provides an effective vehicle for international money laundering, and is a potential source of resources for diverse terrorist groups (LE BILLON 2006; Even-Zohar 2003; Global Witness 2003). The recent release of a major Hollywood film has rekindled international concern for blood diamonds, but progress and attempts to improve the industry, reduce smuggling, and use diamond revenues for local development initiatives have received considerably less attention.

The present post-war diamond mining situation in Sierra Leone is chaotic, with much reported illegal mining and smuggling of diamonds across international borders. In fact, it has been estimated that up to $90 \%$ of the country's diamond production in 2002 was exported illegally, amounting to over US\$ 350 400 million in lost development funding and providing potential fodder for money laundering (MSI 2004). Analysts of the war in Sierra Leone frequently agree that the origins of instability extend back well beyond the last decade, and embody a mixture of factors including an over-centralization of power, a lack of good governance, the denial of fundamental rights, economic mismanagement, and social exclusion (UN 2004). A combination of these factors, many believe, led to the creation of what has often been referred to as a lumpen proletariat of rural youth, many of whom eventually became rebels in the Revolutionary United Front (RUF) (for further discussion see FANTHORPE 2001). A number of commentators have warned that without significant efforts to overcome these forces of exclusion and provide socio-economic opportunities for rural youth, there is a significant risk that violence could break out again. The question thus remains as to whether or not diamonds could become a driver of development, rather than a force of exclusion and instability. The urgent implementation of an effective management scheme for monitoring the mining and marketing of diamonds would seem imperative, given the potentially destabilizing effect on the country of the uncontrolled exploitation of this important resource. A recent report by Management Systems International gives cause for concern, noting that "Only a tiny proportion of the value on the European market value of the exports (approximately 10-15\%) remains to be split among 200,000 to 400,000 miners and diggers. These 15-30 year-old males are the very demographic group that is most likely to resume warfare if left unattended" (MSI 2004, 7).

This paper considers the Sierra Leone diamond mining situation in the context of broader development strategies for post-conflict reconstruction. It is informed by recent field-based research undertaken by the authors in the diamond mining areas of the Eastern Province (e.g. see Binns/Maconachie 2005, 2006), which in turn draws upon the findings of earlier research in the early 1970 s conducted by one of the authors (BINNS 1981, 1982). This research, which focused on the relationships between diamond mining and rural development, was undertaken in the two communities of Kayima (Sandor Chiefdom) and Panguma (Lower Bambara Chiefdom), which are situated some $250 \mathrm{~km}$ from Freetown and less than $100 \mathrm{~km}$ from the Guinea and Liberia borders (Fig. 1). Following a review of literature concerning the resource curse hypothesis and how this might relate to Sierra Leone, two important recent initiatives in the country's diamond economy are then examined: the Kimberley Process Certification Scheme (KPCS) and the Diamond Area Community Development Fund (DACDF). The paper argues that whilst such initiatives are significant steps in addressing a number of key issues, if sustainable development is to be achieved, future policies must be based on a detailed understanding of relation- 
ships between diamond mining and rural development at local, regional and national levels.

\section{The resource curse hypothesis}

The role that diamonds assumed in Sierra Leone's past, and could well assume in the future, ties into larger debates concerning the socalled resource curse syndrome in African countries, where it remains unclear whether an abundance of natural resources is actually a blessing or a hindrance for political and socioeconomic development (Ross 1999). A growing body of research explores this debate, and is located within three general sub-literatures; first, the relationship between resource wealth and economic performance; secondly, the links between resources and civil war; and thirdly, the relationship between resource abundance and the nature of political regimes. For the sake of clarity, we make a distinction here between those works focusing on macro-level aspects of the resource curse, and those focusing on micro-level aspects.
From the macro perspective, while some critics have argued that an over-reliance on natural resources can have adverse consequences for economic growth (AUTY 1993; SACHS/WARNER 1995), others have maintained that, with few exceptions, mineral and resource-rich developing countries are often subjected to continuing underdevelopment, corruption and political instability, leading in some cases to violent civil war (COLLIER/ HoEFfler 2001; Elbadawi/Sambanis 2002). However, as Rosser (2006) concludes from his extensive survey of the resource curse literature, while many studies provide convincing evidence linking natural resource abundance to negative development outcomes, relatively little research adequately examines the role that social forces play in shaping these development outcomes.

Of notable exception, Woolcock et al. (2001) analyse the interaction of social capital with natural resources, demonstrating that social variables can mediate the relationship between natural resource wealth and development.

Fig. 1: Sierra Leone - mining areas and study centres

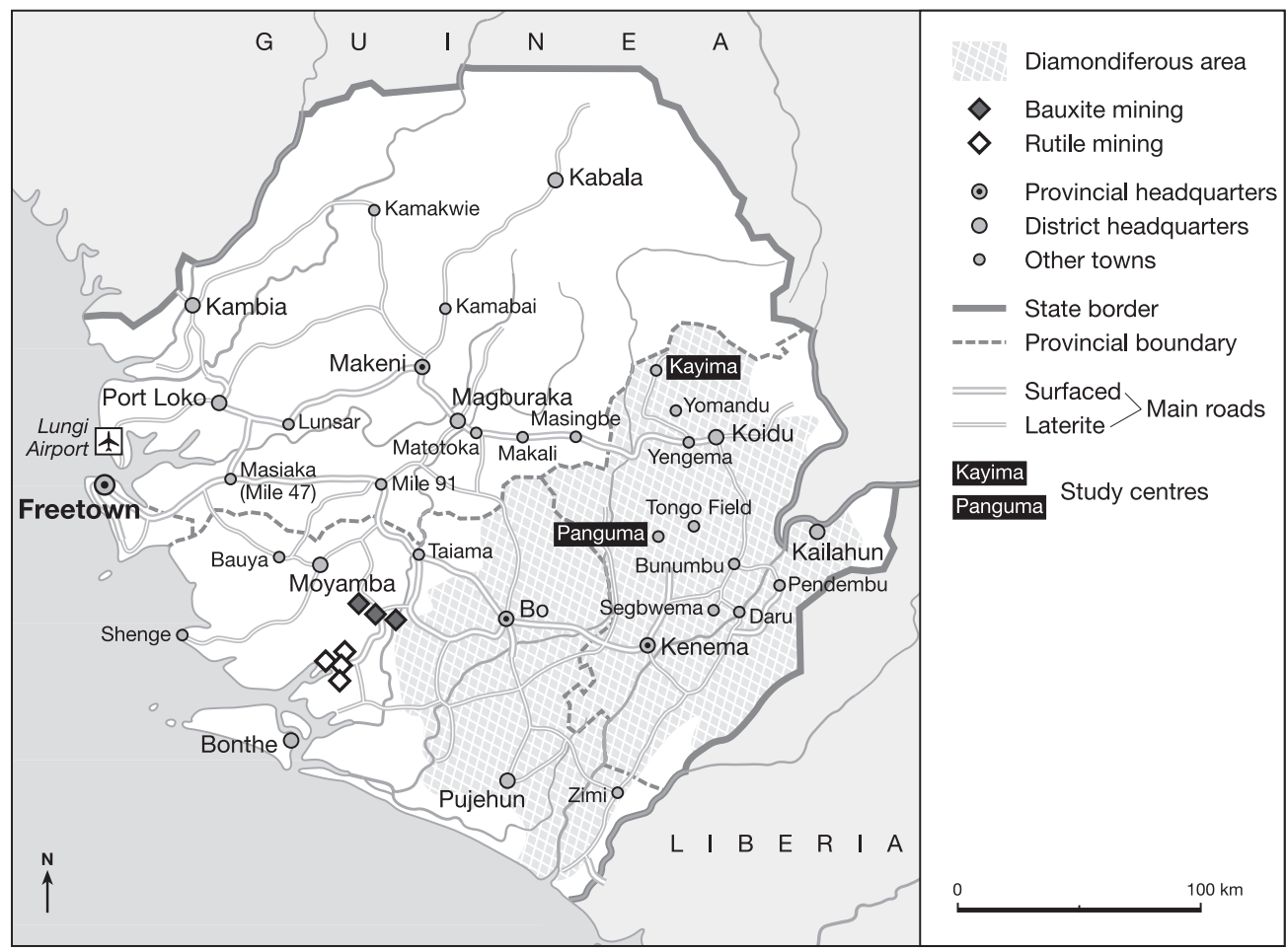


They argue that it is the specific nature of communities, institutions and state-society relations that has a critical impact on economic growth trajectories in general, and on the management of shocks in particular. Elsewhere, ACEMOGLu et al. (2001) suggest that institutions themselves are a more significant determinant of resource-driven outcomes than resource endowment per se. They argue that different types of colonization policies created different sets of institutions in resource-rich countries, which were subsequently inherited by post-colonial societies. Post-independence states often adopted the authoritarian tactics and institutions of their colonizers in order to cement their political power and facilitate the extraction of resources from the rest of society (see RENO 1995 for further discussion of this point, with specific reference to post-colonial Sierra Leone). GlAESER et al. (2004), on the other hand, critically examine the debate concerning whether political institutions cause economic growth or, alternatively, whether growth and human capital accumulation lead to institutional improvement. While they find that exploring the causal link between institutions and economic growth is extremely difficult due to both conceptual problems with the measurement of institutions and the limitations of econometric techniques, they conclude that policy and human capital are in fact more significant variables in measuring growth. More recently, LEDERMAN/MALONEY (2007) use a new measure of resource dependence to suggest that natural resources positively impact upon development and that institutions may sometimes be inversely related to development outcomes. These variable trends in the macro literature, and the fact that econometric analysis appears to yield conflicting conclusions, suggest that specific case study analysis at the micro-level, such as the research presented in this paper, is more important than ever before.

With respect to the links between natural resources, civil war and political regime type, a number of studies have demonstrated a strong correlation between a developing state's reliance on natural resources and the likelihood that it will suffer from conflict (COLLIER/HOEFFLER 2001; ElBADAWI/SAMBANIS 2002). ColLIER/HOEFFLER (1998; 2000; 2002; 2005), for example, found that natural resource abundance and civil war are strongly linked, and demonstrated that the two variables share a curvilinear relationship. In other words, al- though resource wealth may initially be responsible for increasing the risk of civil war, after a certain amount of resource export has been achieved, the risk reduces. A similar study undertaken by REYNAL-QUEROL (2002) found that natural resource abundance is a key variable for explaining the incidence of non-ethnic civil wars and other kinds of political violence, but not the incidence of ethnic civil wars.

Some observers have also suggested that natural resource abundance may actually prolong civil wars. FEARON (2004) suggests that countries with contraband resources, including diamonds and drugs, tend to experience longer civil wars, whilst Ross (2003) has demonstrated that of all the major kinds of natural resources, diamonds and illegal drugs were the most strongly associated with the civil wars occurring between 1990 and 2000. He suggests that it is the 'lootability' of a resource, or whether or not it has a high value-to-weight ratio and can be easily appropriated and transported by unskilled workers, which determines the impact that a particular resource will have on the potential for war ${ }^{3}$. However, Ross (2003) also points out that in non-conflict situations, lootable resources generally produce more widespread benefits for local people and the poor than do unlootable commodities ${ }^{4}$.

Rather than re-visiting arguments that have been rehearsed repeatedly elsewhere, this paper bypasses the debate that is concerned with whether Sierra Leone's civil war was fought with, or over diamonds. Attention is focused instead on the latter point made by Ross (2003) concerning the potential benefits that lootable resources may have for local communities. The thrust of the discussion here explores the role of alluvial diamond mining in the post-conflict scenario, and addresses some key questions concerning the interactions between mining and the rural sector. The paper thus makes a noteworthy contribution to literature focusing on micro aspects of the resource curse, with the discussion building on several important studies that have explored local-level impacts of mining activities on communities. The earlier works by BALDWIN (1956) and BEVAN et al. (1987) provide a useful context for considering the merits of channelling revenue flows through local, rather than national, channels. EGGERT's (2001) more recent overview of literature concerning the economic aspects of mining and the sustainability of 
its benefits is also useful, although he concentrates mainly on large-scale commercial mining and neglects the specific issues surrounding small-scale artisanal mining. Of greater relevance to our discussion, EGGERT (2001) notes how forward, backward and final-demand linkages between mining and other activities can provide a positive multiplier for the regional economy. While AROCA (2001) explores these linkages in the context of the mining sector in northern Chile, highlighting that there are both positive and negative impacts at the community level, PORTER (1984) suggests that using multipliers on their own to rank the desirability of mining for regional development is inappropriate. In short, a full consideration of all social costs associated with mining is necessary in order to obtain a clear picture of its impact on communities. If Sierra Leone is indeed affected by a virulent form of resource curse, we must ask how diamonds might become a driver of development, rather than leading to greater instability and vulnerability? In considering how diamonds and their trade might be better harnessed for poverty reduction, economic growth and social development, it is vital to remember that policies which regulate diamond extraction and governance often produce highly uneven impacts, with enormous wealth and desperate poverty in precisely the same locations. A better understanding of the deeper roots of Sierra Leone's governance problems and lack of development constitutes an essential first step in appreciating how diamond resources can be better harnessed for pro-poor change.

Given the potentially destabilizing effect of the uncontrolled exploitation of diamonds in charting a future development trajectory in post-conflict Sierra Leone, there is now an urgent need for an effective management scheme for both the mining and marketing of this valuable resource. There has been much international recognition of the UN-inspired Kimberley Process Global Certification System for Rough Diamonds, initiated in 2003, and the USAID-funded Peace Diamond Alliance is reportedly making progress with initiatives designed to channel the benefits of diamonds towards local communities. It has also been suggested that as Sierra Leone is moving towards greater political and administrative decentralization, there may be potential for further public participation in resource management decision-making processes, as institutions at all levels are forced to address issues such as democratization, accountability and transparency (RIBOT 2004; Binns et al. 2005). While it would appear that the decentralization of responsibilities for natural resource management should provide great opportunity for increasing the relevance of local authorities to local people, at the same time power sharing can be a threat to central authorities, traditional leaders and elites, who may fear a loss of power, income or patronage resources. Other observers have pointed to the significant political conflict and resistance that have ensued in similar scenarios elsewhere in Africa, where power and resources have been redistributed under the banner of decentralization initiatives (NTSEBEZA 2004).

In short, many initiatives to decentralize structures of government invariably interact with local interests and relationships of power in complicated ways. It therefore remains imperative to question what these initiatives actually mean for local development, in light of the entrenched interests of global capital (whether channelled through legitimate corporations or unregulated rent-seekers) in Sierra Leone's diamond industry, and Africa's resources more broadly. Thus far, neither the OECD Guidelines for Multinational Enterprises, nor the numerous codes of best practice principles devised by the diamond industry itself, have had any impact where transgressors are concerned. During the war, diamond exploitation became a niche market for groups willing to avoid regulation and assume greater risk, and in the post-conflict scenario, it seems that for many transnational corporations (TNC) and other actors, it is a case of business as usual.

In considering the role that diamonds can and should play in Sierra Leone's post-conflict reconstruction and development strategy, we now focus on two important recent initiatives in the country's diamond economy. First, we explore the potential of the Kimberley Process Certification Scheme (KPCS) for strengthening accountability and transparency in government and industry procedures, while at the same time rebuilding international confidence in the country's diamond industry. The question of whether agendas for sustainable policy and practice, such as the KPCS, actually benefit those who are working and living in the diamondiferous areas, is an issue that deserves further investigation. Secondly, consideration 
is given to the establishment of the Diamond Area Community Development Fund (DACDF), whereby a percentage of the diamond export tax is returned to communities where diamonds are mined. Although the DACDF aims to return a small portion of diamond revenue to the communities of origin, and to encourage local commitment to legal mining activities, the effectiveness of this scheme must be examined.

\section{The Kimberley Process}

Unlike South Africa, where diamond mining is associated with the mechanical mining of deep reserves, in Sierra Leone it is not uncommon to find a good quality diamond on the ground surface, particularly after rain. This accessibility of diamonds led to a diamond rush from the 1950s, resulting in a massive influx of people into the Eastern Province. While it is both easy and economically practical for mining companies to strictly control deep kimberlite mining (as in Botswana or South Africa), alluvial diamond fields, like those in Sierra Leone, typically contain relatively few diamonds per hectare, people tend to actually live where the diamonds are, and labour-intensive mining techniques are more common. It is therefore virtually impossible to closely control artisanal alluvial diamond mining.

In recent years, considerable attention has been focused in Sierra Leone on developing the deep kimberlite mining process, as a possible way forward in breaking the link between the legitimate trade in diamonds and uncontrolled conflict diamonds. In other African countries, including South Africa and Botswana, kimberlite deposits have been mined efficiently and profitably, using a secure, high-capital, high technology and low-labour mix. For example, a report compiled by the American consulting firm, Management Systems International (MSI 2004), notes that in Botswana, Debswana produced a gross profit of US $\$ 1.5$ billion in 2001 , employing only 6,000 people, with virtually the entire production being exported legally.

There has been wide recognition of the potential of kimberlite mining in the effective management and marketing of diamonds, in light of the destabilizing effect that diamonds have had on many African countries. As such, in
December 2000, the United Nations General Assembly adopted a resolution supporting the creation of an international certification scheme for rough diamonds. On November $5^{\text {th }}$ 2002, the scheme, known as the Kimberley Process Certification Scheme (KPCS), was adopted at a ministerial meeting in Interlaken, Switzerland. The KPCS is a joint government, international diamond industry and civil society initiative designed to stem the flow of conflict diamonds onto the market, while at the same time protecting the legitimate diamond industry. The scheme officially took effect on January $1^{\text {st }}, 2003$, and nearly 50 countries engaged in diamond production and marketing, including Sierra Leone, are now involved. Although a founding member of the KPCS, Sierra Leone had earlier in October 2000 initiated a certification scheme in accordance with United Nations Security Council Resolution 1306 of July $5^{\text {th }} 2000$. This earlier scheme conforms with the KPCS and continues to be used in Sierra Leone. Since its introduction, diamond exports through the Government Gold and Diamond Office (GGDO) have increased significantly. This is particularly evident when export figures from 1999 (prior to the launch of the certification scheme) are compared with those from 2000 (the first year of the scheme). As Tab. 1 clearly shows, there was a significant increase in export earnings when kimberlite production was initiated in 2003. Thus, as noted by DAVIES (2006, 178), "although conceived for blood or conflict diamonds, the Kimberley Process is proving useful in Sierra Leone's post-conflict context".

But the Kimberley Process is not without its limitations. Some industry observers suggest that up to $50 \%$ of Sierra Leone's diamonds continue to leave the country illegally (Partnership Africa Canada and Network Movement for Justice and Development 2006) ${ }^{5}$. Moreover, there is no mandatory impartial monitoring mechanism associated with the scheme, which in effect allows the industry to monitor itself. As a report from Global Witness/Partnership Africa Canada (2005) recognises, perhaps the major challenge facing the Kimberley Process is to ensure that diamond control systems are effectively implemented and enforced. Certification must be supported by strong control systems to ensure that diamonds are no longer exploited to fund conflict. As has been noted, alluvial diamond mining remains particularly difficult to regulate, and a 
group has been established within KPCS to focus on the challenges associated with implementing systems of control in alluvial diamond producing countries. Recent reports from the Democratic Republic of Congo and Cote d'Ivoire - two countries that are currently engulfed in conflict - suggest that despite an embargo, diamonds continue to flow from both countries and are possibly being exported by other KPCS participants. There is clearly much work to be done in order to ensure that the certification process becomes more credible and effective.

Although the Kimberley Process may be a positive step forward in attempting to redress the serious humanitarian and security problems associated with conflict diamonds, and may have played a role in increasing export earnings for the Sierra Leone government, it has actually done little to address the poverty and desperate working conditions that small-scale miners must endure on a daily basis, both in Sierra Leone and elsewhere. There are an estimated one million artisanal miners in Africa that operate beyond the KPCS (DDI 2005, 2). The Diamond Development Initiative (DDI), which has largely grown out of the Kimberley Process, brings together governments, NGOs and the diamond industry itself, and aims to promote a more developmental focus that centres on miners and mining communities. As SMILlIE (2006, xii) appropriately notes, "In the long run, better remuneration, better conditions and better alternatives are more likely to make a real difference in the artisanal mining sector than more rules, more antipathy and more peacekeeping". The Diamond Area Community Development Fund (DACDF) is one such initiative which is attempting to address these particular issues.

\section{Diamond Area Community Development Fund (DACDF)}

Following the cessation of conflict in Sierra Leone, the Cabinet held its $36^{\text {th }}$ meeting on December $20^{\text {th }} 2001$, and the establishment of the Diamond Area Community Development Fund (DACDF) was formally approved. The fund has been widely heralded as providing a considerable incentive for both diamond miners and resource-rich chiefdoms to engage in legal diamond mining activities and revenue reporting, by returning a percentage of mining revenue to the producing chiefdoms. A portion of the government's $3 \%$ diamond export tax (which amounts to $0.75 \%$ export duty) is now allocated to the fund for small-scale development in diamond communities, and donors are asked to match funding to the DACDF in order to further enhance social and infrastructure development (TEMPLE 2005). To date, the matching arrangement remains unclear, but according to the recent Diamond Industry Annual Review (Partnership Africa Canada and the Network Movement for Justice and Development 2006), by the end of 2004, some 54 chiefdoms with a combined total of 2,313 licences

Tab. 1: Diamond exports from Sierra Leone: 1998-2006 (GGDO)

\begin{tabular}{lrrr} 
Year & Carats & Value (US \$) & Duty 3\% (US \$) \\
1998 & & & \\
1999 & $15,818.04$ & $1,780,287.41$ & $53,408.22$ \\
2000 & $9,320.32$ & $1,244,825.34$ & $37,344.76$ \\
2001 & $77,372.39$ & $10,066,920.81$ & $302,007.62$ \\
2002 & $222,519.83$ & $26,022,492.27$ & $780,674.77$ \\
2003 & $341,859.23$ & $41,732,130.29$ & $1,251,964.71$ \\
$2004(+)$ & $506,723.37$ & $75,969,753.32$ & $2,193,335.84$ \\
$2004(+)$ & $499,242.43(\mathrm{~A})$ & $89,618,053.54$ & $2,688,541.60$ \\
2005 & $58,030.54(\mathrm{~K})$ & $11,172,434.79$ & $335,173.04$ \\
2005 & $552,044(\mathrm{~A})$ & $119,429,528$ & $3,582,885.84$ \\
$2006(*)$ & $116,665(\mathrm{~K})$ & $22,510,716$ & $675,321.48$ \\
$2006(*)$ & $209,762(\mathrm{~A})$ & $45,535,966$ & $1,366,078.98$ \\
\hline
\end{tabular}

(+) Figures from January to September 2004, (*) Figures from January to June 2006, (A) Alluvial, (K) Kimberlite

Source: STRASSER-KING 2004, 9 and GGDO Diamond Export Figures, 2001-2006 
had benefited from the fund. The first tranche was paid for the period January-June 2001, and disbursements have been made every six months since then. The fund is now approaching US \$3 million, and some chiefdoms and councils have used the finances wisely for community infrastructure, education, health and vocational skills training centres (TEMPLE 2005).

Chiefdoms benefit in accordance with the number of mining licences issued and the value of gem-stones recovered from their territory. Funds disbursed are earmarked for community development projects and, according to the Ministry of Mineral Resources (2004), by December 2003, Sandor Chiefdom had been allocated Le 96,586,460 (c. £ 29,074) by the DACDF and Lower Bambara had received Le $112,363,124$ (c. $£ 33,833$ ). As can be seen in Tab. 2, the annual DACDF allocation for 2005 was significantly higher, with Sandor Chiefdom receiving Le 525,131,768.89 (c. £ 158,073), and Lower Bambara receiving Le 303,296,375.06 (c. £ 91,297). Chiefdom administrators in Kayima (Sandor Chiefdom) report that the fund has financed the rehabilitation of the Native Administration (NA) police quarters and lock-up, and the community health centre. In Panguma (Lower Bambara Chiefdom), the fund has been used for the rehabilitation and extension of the community centre.

Tab. 2: DACDF allocation of funds 2005
In addition to providing much-needed resources for social and economic development, the fund is (in theory) supposed to encourage chiefdoms to monitor mining more effectively and eradicate illegal activities, thereby enhancing the certification system. However, the disbursement of funds and the capacity of communities to monitor development projects have provoked a considerable amount of controversy among critics. In 2002, a series of ad hoc reports were produced by industry observers, revealing that a number of chiefdoms were not utilizing the fund competently, and in 2003 a coalition was set up to ensure more effective use of the fund 6 . Concerns continued to be raised by the Government of Sierra Leone's High Level Diamond Steering Committee, and the disbursement of funds was actually suspended during 2004. One of the main concerns highlighted by the Committee involved the apparent lack of transparency, community awareness and local participation in decision-making processes concerning the use of the fund. Although Chiefdom Development Committees (CDCs) have been put in place to supposedly ensure that project decision-making is carried out in a fair and accountable way, CDCs are often composed entirely of rural elites such as Section Chiefs, which has stifled the concept of local ownership by alienating other key stakeholders, such as women and youth (TEMPLE 2005) ${ }^{7}$.

\section{Sandor Chiefdom Sandor Chiefdom Sandor Chiefdom January-June 2005 July-December 2005 Yearly Allocation of DACDF - 2005}

\begin{tabular}{|c|c|c|c|}
\hline Number of mining licences issued & 455 & 451 & - \\
\hline Total Amount Due (Le) & $254,103,085.90$ & $271,028,682.99$ & - \\
\hline Amount to District Council (Le) & $50,820,617.18$ & $54,205,736.60$ & - \\
\hline \multirow[t]{2}{*}{ Amount to Chiefdom (Le) } & $203,282,468.72$ & $216,822,946.39$ & $525,131,768.89$ \\
\hline & $\begin{array}{l}\text { Lower Bambara } \\
\text { Chiefdom } \\
\text { January-June } 2005\end{array}$ & $\begin{array}{l}\text { Lower Bambara } \\
\text { Chiefdom } \\
\text { July-December } 2005\end{array}$ & $\begin{array}{l}\text { Lower Bambara } \\
\text { Chiefdom } \\
\text { Yearly Allocation } \\
\text { of DACDF - } 2005\end{array}$ \\
\hline Number of mining licences issued & 218 & 211 & - \\
\hline Total Amount Due (Le) & $176,495,816.06$ & $126,800,559.00$ & - \\
\hline Amount to District Council (Le) & $35,299,163.21$ & $25,360,111.80$ & - \\
\hline Amount to Chiefdom (Le) & $141,196,652.85$ & $101,440,447.20$ & $303,296,375.06$ \\
\hline
\end{tabular}


While many chiefdoms have demonstrated the capacity to utilize the fund effectively, it is also apparent that many have not. JACKSON (2007) highlights the misuse of the fund, pointing out that, "there is no accountability mechanism for ensuring that this cash is used for development, and it is extremely common to hear that local people complain of the chief's abuse of the system in pocketing this money" $(2007,100)$. In comparing the two chiefdoms where fieldwork was undertaken for this study (Sandor and Lower Bambara), it is evident that there is a great deal of variability in how DACDF funds have been utilized. In a report by the USAID-funded Integrated Diamond Management Program (IDMP), for submission to the Government of Sierra Leone High Level Diamond Steering Committee, the accountability performance of Sandor Chiefdom was found to be very poor. For example, according to the report, the chiefdom was allocated Le 198,673,372 in 2004, but at the time monitoring was undertaken, it was noted that Le $155,000,000$ was allegedly in the chiefdom bank account, and there were no records accounting for the expenditure of the remaining Le 43,673,372 (TEMPLE 2005). In the previous year (2003) Sandor Chiefdom received Le 71,060,019 from the fund, but a grossly disproportionate amount of the disbursement was spent on the rehabilitation of the chiefdom's Native Administration police barracks, a decision that was made solely at the discretion of the Regent Chief, since there was no Paramount Chief at the time. The report concluded that the issue of local governance in San-dor Chiefdom required urgent attention if the DACDF is to be utilized effectively in future ${ }^{8}$.

In comparison, the report notes that although the use of DACDF funds is rather better in Lower Bambara Chiefdom, there was a slight decrease in accountability, performance and project quality between 2003 and 2004. It is suggested that this was because there was a desire to satisfy widespread community needs, which led to too many projects being initiated. In 2004, nine projects (one in each section of the chiefdom) were targeted and implemented in Lower Bambara, but many of these were small and inadequately funded. The report notes that Lower Bambara received Le $167,342,890$ from the fund in 2004 , with 86.23 $\%$ of the allocation effectively utilized for chiefdom projects.
Although the DACDF is a significant initiative, it has frequently been at the centre of controversy. While early disbursements were made directly to paramount chiefs, and many could not subsequently account for expenditure, much has changed in Sierra Leone since the DACDF was first approved in 2001. Most notably, the Local Government Act had not been enacted at the time that DACDF was proposed, and Local Councils, which are now also beneficiaries of the fund, have a role to play in the implementation of the fund. Although it could be argued that the evolving decentralization process should improve the management of the funds, it may also be the case that the reintroduction of Local Councils has created further conflict and confusion which could impact on the rational use of funds.

\section{Conclusion}

Diamonds in Sierra Leone have been, and will continue to be, inextricably linked to both development and national and sub-regional security. In the context of the resource curse, the country undoubtedly has a valuable, but eminently lootable resource, and some strategy must be formulated by which both national and local economies can benefit from a more effective and sustainable form of exploitation of this resource. The essence of such a strategy seems to be that it should ultimately be in the interests of local communities to operate both efficiently and transparently in mining and trading diamonds. But this will only occur if there is the incentive of a fair proportion of the benefits being actually returned to local people, and if both nationally and locally there is a popular sense of tangible gain from diamond mining. A recent study commissioned by the UK Department for International Development (DfID), which seeks to deepen the understanding of Sierra Leone's political economy, and to highlight the principal drivers and impediments to pro-poor change, accurately summarizes the dilemma facing Sierra Leone: "Whether the diamond sector provides a strong or a rotten foundation upon which Sierra Leone can rebuild depends on the ability of the state to regulate the mining and trade of diamonds, to sustain the shift in production from the illicit to the formal sector, and to garner and fairly distribute revenue from the mining and sale of diamonds" (BROwN et al. 2006, 6). 
Whilst the Alluvial Diamond Mining Scheme (ADMS), introduced by the government in the 1950s, was not without its problems, a similar controlled process of application and issuing of mining licences, together with effective policing of such a process, could well be a way forward. Although there is currently a licensing system in place under the Mines and Minerals Act of 1994, other elements will need to be put into place, notably policy mechanisms to control the buying, trading and smuggling of diamonds, which can ensure that appropriate financial awards are actually returned to local authorities where the diamonds were mined. Progress has been made with the Kimberley Certification Scheme as an important vehicle in seeking to clean up the diamond industry, and the initiation of the DACDF as a means of returning diamond revenues to local communities. But there needs to be a more detailed understanding of the complex relationships between mining, the environment and local communities. There is no doubt that the introduction of a complex monitoring and reward process provides significant challenges for a country which is emerging from a long period of conflict, is suffering from significant shortages of financial and skilled human capacity, and where good governance and accountability will undoubtedly take some considerable time to develop.

\section{Notes}

1 In studies concerning the political economy of war, the literature remains divided over the relative importance that each of these causal factors assumes in the incidence of conflict. While the greed theory argues that looting and resource capture are the prime motives for rebel actors, proponents of the grievance theory maintain that justiceseeking for the marginalization of social groups remains the key factor leading to violent rebellion.

2 In fieldwork carried out for this paper, informants from the diamond area of Tongo Field, near Panguma, were able to provide detailed accounts of widespread and uncontrolled mining by the Revolutionary United Front (RUF) during the conflict, describing how even the secondary school playing field and the airstrip were dug up by rebels in a desperate desire to fund their war efforts.

3 Ross (2003) notes that natural resources tend to have a different impact on separatist conflicts than they do on non-separatist conflicts. Unlootable resources such as oil, natural gas, or deep-shaft minerals, are more commonly associated with prolonged separatist conflicts.
4 The logic for this observation lies in the fact that lootable resource extraction relies more heavily on the use of unskilled labour, whereas the extraction of unlootable resources requires a higher degree of skilled labour and capital. In other words, unlootable resources are more likely to generate revenues for skilled labourers, for those who have access to the capital required for extraction, or for the government. In poor developing countries, particularly in Africa, individuals who possess these criteria are more likely to come from outside the region of extraction, and possibly even from outside the country. For example, in the oil producing regions of the Niger River Delta in southern Nigeria, where foreign capital and labour dominate the oil extraction process, local communities, such as the Ogoni people, remain largely marginalized and poor (this is well described in WATTS 1997).

5 DAVIES $(2006,178)$ explains that the combination of requirements to pay an exporter's licence fee of US\$ 30,000 per year, the export tax of $3 \%$, and the additional payments which must be made through bribes, have all contributed to discouraging legal production.

6 A recent study by MSI $(2004,5)$ reports that the DACDF Coalition - a union of representatives from the Ministry of Mineral Resources, Ministry of Local Government, national and international NGOs, the Anti-Corruption Commission and the Miners' Union - is working with traditional leaders in diamondiferous chiefdoms to help chiefs improve their responsiveness to community interests and accountability for funds. The report notes, "Constant sensitization, reporting on mis-spending, and refusal by central government to accept mismanagement of DACDF funds, has resulted in a remarkable turnaround in fiscal responsibility. Whereas fully $60 \%$ of the first tranche of DACDF funds disappeared, by the most recent tranche almost ninety percent of all funds were accounted for - including recovery of some of those funds missing initially" (MSI 2004, 4).

7 Other observers have noted that in the post-war period, the relationship between the Native Administration and the community at large is highly unequal, and has frequently resulted in the development of a rift between youths and chiefs in the countryside. Richards (2005) suggests that the war was largely a product of this division, and there continues to be considerable dissatisfaction among youths with the hierarchical political structures in the countryside.

8 Elsewhere, the World Bank has been highly critical of rule by the chiefs, noting that their re-instatement has been characterised by mismanagement of funds, abuse of power and an inability to deliver basic services (World Bank 2003).

\section{References}

Acemoglu, D./Johnson,S./Robinson, J. (2001): The colonial origins of comparative development: 
An empirical investigation. In: American Economic Review, (91)5, 1369-1401.

ArocA, P. (2001): Impacts and development in local economies based on mining: The case of the Chilean II region. In: Resources Policy, 27, 119-134.

Auty, R. (1993): Sustaining development in mineral economies: The resource curse thesis. London, New York.

BALDWIN, R.E. (1956): Patterns of settlement in newly settled regions. In: Manchester School of Social and Economic Studies, 24, 161-79.

BAnnon, I./ Collier, P. (eds.)(2003): Natural resources and violent conflict: Options and actions. Washington, D.C. (World Bank).

Berdal, M./Malone, D. (eds.)(2000): Greed and grievance; economic agendas in civil wars. Boulder.

Bevan, D.L./Collier, P./Gunning, J.W. (1987): Consequences of a commodity boom in a controlled economy: Accumulation and redistribution in Kenya. In: World Bank Economic Review, 1, 489513.

BINNS, J.A.(Tony)(1981): The dynamics of Third World food production systems: an evaluation of change and development in the rural economy of Sierra Leone. Birmingham. (PhD thesis, Centre of West African Studies, University of Birmingham).

BINNS, J.A. (Tony)(1982): The changing impact of diamond mining in Sierra Leone. Brighton. (University of Sussex Research Papers in Geography, No. 9, University of Sussex, Brighton).

Binns, T./Porter, G./Nel, E./Kyei, P. (2005): Decentralising poverty?: Reflections on the experience of decentralisation and the capacity to achieve local development in Ghana and South Africa. In: Africa Insight, (35)4, 21-31.

Binns, T./MaconachiE, R. (2005): Going home in post-conflict Sierra Leone: Diamonds, agriculture and re-building rural livelihoods in the Eastern Province. In: Geography, (90)1, pp.67-78.

Binns, T./Maconachie, R. (2006): Post-conflict reconstruction and sustainable development: Diamonds, agriculture and rural livelihoods in Sierra Leone. In: International Journal of Environmental, Cultural, Economic and Social Sustainability, (2)3, 205-216.

Brown, T./FANTHORPE, R./GARDENER,J./ GBERIE,L./ GibrIL SESAY, M. (2006): Sierra Leone: Drivers of change. Bristol. (The IDL Group, Brockley Combe, Backwell, Bristol, March 2006).

Collier, P. (2000): Economic causes of civil conflict and their implications for policy. Washington, D.C. (The World Bank).

Collier, P./Hoeffler, A. (1998): On economic causes of civil war. In: Oxford Economic Papers, 50, 563-73.

Collier, P./Hoeffler, A. (2000): Greed and grievance in civil war. Washington, D.C. Internet: http://worldbank.org/research/conflict/papers/greedhtm, 26 April. (World Bank).
Collier, P./Hoeffler, A. (2001): Greed and grievance in civil war. Washington, D.C. (Policy Research Working Paper no. 2355. World Bank).

Collier, P./Hoeffler, A. (2002) The Political Economy of Secession, 23 December, Washington, D.C: Development Research Group, World Bank.

Collier, P./HoEffler, A. (2005): Resource rents, governance and conflict. In: Journal of Conflict Resolution, (49)4, 625-33.

DAvies, V. (2006): Diamonds, poverty and war in Sierra Leone. In: Hilson, G. (ed.) (2006): SmallScale Mining, Rural Subsistence and Poverty in West Africa. Rugby, 165-180.

Diamond Development Initiative (DDI) (2005): Diamond Development Initiative: Background note. Avvra. (Accra Conference, October 27-30, 2005. Internet: http://casmsite.org/Documents/DDI_Accra_Oct05.pdf.

DUFFIELD, M. (2001): Global Governance and the New Wars: The Merging of Development and Security. Zed Books, London.

DuFFY, R. (2007): Questioning environmental security: A political ecology of illicit trading networks. Chicago. (Unpublished paper presented at the International Studies Association, Chicago, 2007).

EgGERT, R.G. (2001) Mining and Economic Sustainability: National Economies and Local Communities. MMSD Paper No. 19. IIED, London.

Elbadawi, I./ SAmbanis, N. (2002): How much war will we see? Estimating the prevalence of civil war in 161 countries, 1960-1999. In: Journal of Conflict Resolution, (46)2, 307-334.

Even-ZoHar, C. (2003) Financial constraints study, June 2003. Internet: www.peacediamonds.org.

FANTHORPE, R. (2001): Neither citizen nor subject? 'Lumpen' agency and the legacy of Native Administration in Sierra Leone. In: African Affairs, 100, 363-386.

FEAron, J. (2004) Primary commodity exports and civil war. In: Journal of Conflict Resolution, (49)4, 483-507.

Glaeser, E.L./LA Porta, R./Lopes-De-Silanes, F./SHLEIFER, F. (2004): Do institutions cause growth? Cambridge MA. (National Bureau of Economic Research, NBR Working Paper 10568).

Global Witness/ Partnership Africa Canada (2005): Implementing the Kimberley Process. Ottawa.

Global Witness (2003): For a few dollars more: How al Qaeda moved into the diamond trade. Ottawa.

HOMER-DiXon, T. (1999): Environment, scarcity and violence. Princeton, NJ.

JACKSON, P (2007): Reshuffling an old deck of cards? The politics of local government reform in Sierra Leone. In: African Affairs, 106/422, 95-111.

KALDOR, M. (22006): New and old wars: Organized violence in a global era. Cambridge.

KAPlAN, R (1994): The coming anarchy: How scarcity, crime, overpopulation, tribalism and dis- 
ease are rapidly destroying the social fabric of our planet. In: Atlantic Monthly. Internet: http:// www.TheAtlantic.com/atlantic/election/connection/ foreign/anarcf.htm.

KeEN, D. (1998): The economic functions of violence in civil wars. Oxford.

KeEN, D. (2005): Conflict and collusion in Sierra Leone. Oxford.

LE BILlon, P. (2001): Angola's political economy of war: The role of oil and diamonds, 1975-2000. In: African Affairs, 100, 55-80.

LE BILlon, P. (2006): Fatal transactions: Conflict diamonds and the (anti) terrorist consumer. In: Antipode, (38)4, 778-801.

Lederman, D./Maloney, W.F. (2007): Natural Resources: Neither Curse nor Destiny. Stanford, 1-12.

Management Systems International (MSI) (2004): Integrated diamond management in Sierra Leone: A two-year pilot project. Washington D.C. (Report prepared for assistance of the United States Agency for International Development, April 2004).

Matthew, R./Halle, M./Switzer, J. (2002): A growing threat? In: Matthew, R./Halle, M./Switzer,J. (eds.): Conserving the peace: Resources, livelihoods and security. Geneva, 4-21.

NTSEBEZA, L. (2004): Democratic decentralization and traditional authority: Dilemmas of land administration in rural South Africa. In: Ribot, J./Larson, A. (eds.): Democratic decentralization through a natural resource lens: Experiences from Africa, Asia and Latin America. In: The European Journal of Development Research, (16)1, 71-89.

Partnership Africa Canada and the Network Movement for Justice and Development (2006): Diamond industry annual review: Sierra Leone 2006. Ottawa.

PorTer, M.G. (1984): Mining and the economy some key issues. In: Cook, L.H./Porter, M.G. (eds.): The minerals sector and the Australian economy. Sydney, 1-35.

RENO, W. (1995): Corruption and state politics in Sierra Leone. Cambridge.

REYNAL-QUEROL, M. (2002): Ethnicity, political systems, and civil wars. In: Journal of Conflict Resolution, 46, 29-54.

Riвот, J. (2004): Waiting for democracy: The politics of choice in natural resource decentralization. Washington D.C. (World Resources Institute).

RICHARDS, P. (2003): The political economy of internal conflict in Sierra Leone. The Hague. (Working Paper 21. Netherlands Institute of International Relations Clingendael, Conflict Research Unit, August 2003).

RichaRDS, P. (2005): To fight or to farm? Agrarian dimensions of the Mano River conflicts (Liberia and Sierra Leone). In: African Affairs, (104)417, 571-590.

Ross, M. (1999): The political economy of the resource curse. In: World Politics, (51)2, 297-322.

Ross, M.L. (2003): Oil, drugs and diamonds: The varying roles of natural resources in civil war. In:
Ballentine, K./Sherman, J. (eds.): The Political Economy of Armed Conflict: Beyond Greed and Grievance. Boulder, London, 47-70.

Rosser, A. (2006) The political economy of the resource curse: A literature survey. IDS Working Paper 268, Institute of Development Studies, Brighton, April 2006.

SACHS, J.D./WARNER, A.M. (1995): Natural resource abundance and economic growth. Cambridge, MA. (National Bureau of Economic Research and Harvard University, Working Paper 5398).

SMILLIE, I. (2000): Getting to the heart of the matter: Sierra Leone, diamonds and human security. In: Social Justice, (27)4, 24-31.

SMILLIE (2006): Forward. In: Hilson, G. (ed.): SmallScale Mining, Rural subsistence and Poverty in West Africa. Rugby, xi-xii.

Smillie, I./,Gberie, L./Hazleton, R. (2000): The heart of the matter. Sierra Leone, diamonds and human security. Ottawa. (Partnership Africa Canada).

StRASSER-KING, V.E.H. (2004): The Kimberley process in Sierra Leone and the need for legislation. Freetown. (Paper presented at the Law Reform Commission, Mines and Minerals Seminar on the Development of a Consolidated Mines and Minerals Act for Sierra Leone, November 18-19, 2004).

TEMPLE, P. (2005): Improving the effective use of the Diamond Area Community Development Fund (DACDF). Washington, D.C. (Report by the Integrated Diamond Management Program, IDMP, for submission to the Government of Sierra Leone High Level Diamond Steering Committee, HLDSC. Management Systems International).

Temple, H (2006): Livelihoods report. Freetown. (Report prepared for DfID).

UN (2004): United Nations transitional appeal for relief and recovery: Sierra Leone 2004. Freetown.

UNDP (United Nations Development Programme)(2006): Human development report 2006. Basingstoke.

United Nations Panel of Experts (2002): Final report of the panel of experts of the illegal exploitation of natural resources and other forms of wealth of the Democratic Republic of Congo. New York. (United Nations Security Council S/2002/1146. Internet: http://www.un.dk/doc/S20021146.pdf, 16 October).

WATTS, M. (1997): Black gold white heat: State violence, local resistance and the national question in Nigeria. In: Pile, S./Keith, M. (eds.): Geographies of Resistance. London, 33-67.

WoOlcock, M./Pritchett, L./Isham, J. (2001): The social foundations of poor economic growth in resource-rich countries. In: Auty, R.M. (ed.): Resource abundance and economic development. Oxford, 76-92.

World Bank (2003): Sierra Leone: Strategic options for public sector reform. Washington D.C. (Report no. 25110). 